\title{
Influence of the IUD on ovarian activity in the hamster and rat
}

\author{
W. J. Bo, W. A. Krueger and C. M. Bartley \\ Department of Anatomy, Bowman Gray School of Medicine, Wake Forest University, \\ Winston-Salem, North Carolina 27103, U.S.A.
}

Although studies have shown that an IUD inhibits implantation in the hamster (Orsini, 1965; Richardson \& Ansbacher, 1971) and rat (Doyle \& Margolis, 1964) the mechanism involved is not clear. Saksena, Lau \& Castracane (1974) suggested that inhibition of implantation in the hamster was due to a decrease in progesterone secretion from the ovary adjacent to the IUD which was brought about by an increase in prostaglandin secretion from the IUD-containing horn. Prasad, Joshi \& Labhsetwar (1973) reported a reduction in progesterone secretion from the ovary adjacent to the IUD in the rat and concluded that this change partly accounted for the local antifertility effects of the device. It is not clear from these studies, however, whether the ovaries adjacent to the IUD can maintain pregnancy in the other horn and we therefore examined the effects of a unilateral IUD on the maintenance of pregnancy in rats and hamsters.

\section{Experiment 1}

This study was to determine whether a polyethylene IUD has a similar effect on implantation in the hamster as has been reported for the rat (Bo \& Krueger, 1972; Bo, Krueger \& Garrison, 1972). Golden hamsters (Mesocricetus auratus), 60-75 days of age, were allowed free access to Purina lab chow and water and were maintained in a photoperiod of $12 \mathrm{hr}$ light/24 hr. At the fourth observed oestrus an intrauterine device (10-12 mm long) was inserted under ether anaesthesia into the cervical end of one uterine horn by piercing the antimesometrial wall. The device was either a silk thread $(3 / 0)$ or a polyethylene tube $(0 . d .=0.6 \mathrm{~mm})$. All animals were mated at the next oestrus (Day 1$)$ with a male of proven fertility and divided into two groups. The hamsters in Group I were killed on Days 9-11 of pregnancy and the numbers of implantation sites and CL in each horn and ovary were determined (Table 1). The animals in Group II were killed 8-10 hr after mating. The oviducts were fixed in Bouin's fluid and processed for histological determination of the number of ova ipsilateral and contralateral to the device (Table 1). Implantation and CL number were clearly affected by the presence of an IUD, but the number of eggs shed was not.

Table 1. The effects on ovulation, $C L$ and implantation number (mean \pm S.E.M.) of two types of IUD in the hamster

\begin{tabular}{|c|c|c|c|c|c|c|c|}
\hline \multirow[b]{2}{*}{$\begin{array}{l}\text { Type of } \\
\text { IUD }\end{array}$} & \multirow[b]{2}{*}{$\begin{array}{l}\text { No. of } \\
\text { animals }\end{array}$} & \multicolumn{2}{|c|}{ Implantation sites* } & \multicolumn{2}{|c|}{ Corpora lutea* } & \multicolumn{2}{|c|}{ Ova† } \\
\hline & & $\begin{array}{c}\text { Control } \\
\text { horn }\end{array}$ & $\begin{array}{l}\text { IUD } \\
\text { horn }\end{array}$ & $\begin{array}{c}\text { Control } \\
\text { ovary }\end{array}$ & $\begin{array}{l}\text { IUD } \\
\text { ovary }\end{array}$ & $\begin{array}{l}\text { Control } \\
\text { oviduct }\end{array}$ & $\begin{array}{c}\text { IUD } \\
\text { oviduct }\end{array}$ \\
\hline Silk & 16 & $6.8 \pm 0.6$ & $0 \ddagger$ & $6.9 \pm 0.6$ & $1.1 \pm 0.4 \ddagger$ & $6.2 \pm 0.8$ & $5 \cdot 0 \pm 1 \cdot 2$ \\
\hline Polyethylene & 15 & $5.8 \pm 0.5$ & $0 \ddagger$ & $6.5 \pm 0.5$ & $1.3 \pm 0.3 \ddagger$ & $6.6 \pm 1.3$ & $5.7 \pm 0.3$ \\
\hline
\end{tabular}

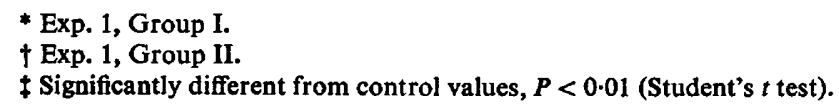

\section{Experiment 2}

In this study to determine whether the ovary adjacent to the silk IUD could maintain pregnancy in the contralateral horn of the hamster, silk thread IUDs were inserted throughout the entire length of 
one uterine horn in mature virgin hamsters on the day of oestrus. The hamsters were mated (Day 1) and on Day 6 of pregnancy the ovary contralateral to the device was removed under ether anaesthesia. In control hamsters, which did not receive an IUD, the right and/or left ovary was removed randomly. The hamsters were killed on Day 13 and the numbers of $C L$ in the remaining ovary, fetuses and resorption sites were determined. Implantation was completely suppressed in all hamsters that were bilaterally ovariectomized on Day 6 of pregnancy. In the control animals with one ovary intact, implantation and fetal development occurred in the horn adjacent to the ovary and in the contralateral horn, but there were no fetuses in either horn in the hamsters with a unilateral silk IUD (Table 2). The mean \pm S.E.M. number of CL in the ovaries removed on Day 6 was $6 \cdot 6 \pm 0.4$ in the controls and $5.7 \pm 0.6$ in the IUD-containing animals. The hamsters with an IUD and adjacent in tact ovary began to cycle again 8 or 9 days after mating.

Table 2. The ability of the ovary on the side of a silk IUD to maintain pregnancy in the contralateral horn of unilaterally ovariectomized hamsters and rats (values are mean \pm S.E.M.)

\begin{tabular}{|c|c|c|c|c|}
\hline $\begin{array}{l}\text { Species/ } \\
\text { treatment }\end{array}$ & $\begin{array}{c}\text { No. of } \\
\text { animals }\end{array}$ & $\begin{array}{l}\text { No. of LC } \\
\text { at autopsy }\end{array}$ & $\begin{array}{l}\% \text { of animals } \\
\text { with fetuses }\end{array}$ & $\begin{array}{l}\text { No. of } \\
\text { fetuses }\end{array}$ \\
\hline \multicolumn{5}{|l|}{ Hamster } \\
\hline Control & 7 & $\begin{array}{c}6.4 \pm 0.4 \\
-\end{array}$ & $\begin{array}{l}100 \\
100\end{array}$ & $\begin{array}{l}5.7 \pm 0.6 \\
5.6 \pm 0.6\end{array}$ \\
\hline Experimental & 9 & 0 & $\begin{array}{l}0 \\
0\end{array}$ & $\begin{array}{l}0 \\
0\end{array}$ \\
\hline \multicolumn{5}{|l|}{ Rat } \\
\hline Control & 14 & $\begin{array}{c}6.6 \pm 0.4 \\
-\end{array}$ & $\begin{array}{l}100 \\
100\end{array}$ & $\begin{array}{l}5.5 \pm 0.6 \\
4.8 \pm 0.6^{*}\end{array}$ \\
\hline Experimental & 10 & $\begin{array}{c}6 \cdot 2 \pm 0 \cdot 6 \\
-\end{array}$ & $\begin{array}{c}0 \\
100\end{array}$ & $\begin{array}{c}\overline{0} \\
3 \cdot 6 . \pm 0 \cdot 5 *\end{array}$ \\
\hline
\end{tabular}

* Means not significantly different, $P>0 \cdot 1$ (Student's $t$ test).

\section{Experiment 3}

The design of this experiment was similar to that of Exp. 2 except that rats were used. Young adult female Holtzman rats were housed in a room maintained at $21^{\circ} \mathrm{C}$, exposed to a light schedule of $14 \mathrm{hr}$ light/24 hr and had free access to food and water. A silk IUD (3/0) was inserted under ether anaesthesia along the entire length of the right or left uterine horn; control rats did not receive an IUD. The rats were mated 3 weeks later (Day 1) and on Day 5 of pregnancy the control animals were unilaterally or bilaterally ovariectomized under ether anaesthesia. The ovary contralateral to the horn containing the IUD was removed in the experimental rats. All rats were killed on Day 15; the uterine horns were examined for fetuses and the number of $C L$ was counted. In the rats that were bilaterally ovariectomized implantation was completely suppressed. Implantation and fetal development occurred in both horns of the control animals that has one intact ovary (Table 2). In rats with an IUD in one horn and the adjacent ovary intact, there were no implantations in the IUD-containing horn but fetuses were present in the contralateral horn. The mean \pm S.E.M. number of $C L$ in the ovaries removed on Day 5 was $6.0 \pm 0.5$ for the controls and $5.9 \pm 0.6$ in the experimental rats.

These results show that there is a difference between the rat and the hamster in the effect of the IUD on ovarian function, and suggest a difference in the mechanism of action of the IUD in the two species. The ovary adjacent to the IUD appears to be unable to maintain pregnancy in the hamster because the CL have failed to develop or have regressed. Ovulation was not affected by the IUD, as found by Saksena \& Shaikh (1974), and normal cyclic activity was resumed. Saksena et al. (1974) observed an increase in the PGF content of the IUD-containing horn on Day 4 of pregnancy in the hamster and suggested a luteolytic effect. Prostaglandin F-2 $\alpha$ has been shown to terminate pregnancy in the hamster by causing regression of the CL (Gutknecht, Wyngarden \& Pharriss, 1971) and our 
results support this concept of IUD action in the hamster. The maintenance of pregnancy in the rat by the ovary on the side of the IUD demonstrates that this ovary is functional and the IUD in this species presumably acts through an alteration of the uterine environment, as suggested by other studies (Doyle \& Margolis, 1964; Parr, Schaedler \& Hirsch, 1967; Bo, Krueger \& Garrison, 1973; Krueger, Bo \& Garrison, 1973).

In addition to the different effects of the IUD on ovarian function in the hamster and rat, our data show that there is a difference in the response to a polyethylene IUD. In the hamster complete suppression of implantation was observed in the horn containing the device, whereas implantation occurred cephalad to the IUD in $67 \%$ of rats (Bo \& Krueger, 1972; Bo et al., 1972). These data further indicate that the mechanisms of action of the IUD differ in the hamster and the rat.

This investigation was supported by USPHS grant HD-06210-04.

\section{References}

Bo, W.J. \& KRUEGER, W.A. (1972) The antiimplantation effect of the polyethylene IUD in the rat. Contraception 5, 319-325.

Bo, W.J., Krueger, W.A. \& Garrison, B.M. (1972) The effect of the polyethylene IUD on rat embryogenesis. Contraception 6, 305-314.

Bo, W.J., KRUEGER, W.A. \& GarRison, B.M. (1973) Implantation of the rat blastocyst following polyethylene IUD sham treatment. Contraception 8, $555-560$.

DOYLE, L.L. \& MARGolis, A.J. (1964) Intrauterine foreign body. I. Effect on reproductive processes in the rat. Fert. Steril. 15, 597-606.

Gutknecht, G.D., Wyngarden, L.J. \& PharRiss, B.B. (1971) The role of $\mathrm{PGF}_{2 \alpha}$ on ovarian and plasma progesterone levels in the pregnant hamster. Proc. Soc. exp. Biol. Med. 136, 1151-1157.

Krugger, W. A., Bo, W.J. \& Garrison, B.M. (1973) The influence of IUDs on uterine neutrophils. Contraception 7, 243-249.

ORsiNI, M.W. (1965) Effect of an intrauterine foreign body on the cycle and pregnancy in the hamster, Mesocricetus auratus (Waterhouse). Anat. Rec. 151, 468, Abstr.
ParR, E.L., Schaedler, R.W. \& Hirsch, J.G. (1967) The relationship of polymorphonuclear leukocytes to infertility in uteri containing foreign bodies. $J$. exp. Med. 126, 523-538.

Prasad, D.S.M., Joshi, H.S. \& LabhSetwar, A.P. (1973) Effects of an intrauterine device on ovarian secretion of progesterone and oestrogens in pregnant rats: evidence for local effects. $J$. Reprod. Fert. 33, 519-522.

RichARDSON, D.W. \& ANSBACHER, R. (1971) The effects of an intrauterine device on pregnancy in the golden hamster. J. Reprod. Fert. 25, 171-175.

Saksena, S.K. \& Shaikh, A.A. (1974) Effect of intrauterine devices on preovulatory $\mathrm{LH}$ and progesterone levels in the cyclic hamster. J. Reprod. Fert. 38, 205-210.

Saksena, S.K., LaU, I.F. \& Castracane, V.D. (1974) Prostaglandin mediated action of IUDs. (II) F prostaglandins (PGF) in the uterine horn of pregnant rats and hamsters with intrauterine devices. Prostaglandins 5, 97-106.

Received 31 March 1976 